IZA DP No. 8795

Schooling, Marriage and Age of First Birth in Madagascar

Peter Glick

Christopher Handy

David E. Sahn

January 2015 


\title{
Schooling, Marriage and Age of First Birth in Madagascar
}

\author{
Peter Glick \\ RAND Corporation \\ Christopher Handy \\ Cornell University \\ David E. Sahn \\ Cornell University, \\ IZA and CERDI
Discussion Paper No. 8795
January 2015 \\ IZA
P.O. Box 7240
53072 Bonn
Germany
Phone: +49-228-3894-0
Fax: +49-228-3894-180
E-mail: iza@iza.org

\begin{abstract}
Any opinions expressed here are those of the author(s) and not those of IZA. Research published in this series may include views on policy, but the institute itself takes no institutional policy positions. The IZA research network is committed to the IZA Guiding Principles of Research Integrity.

The Institute for the Study of Labor (IZA) in Bonn is a local and virtual international research center and a place of communication between science, politics and business. IZA is an independent nonprofit organization supported by Deutsche Post Foundation. The center is associated with the University of Bonn and offers a stimulating research environment through its international network, workshops and conferences, data service, project support, research visits and doctoral program. IZA engages in (i) original and internationally competitive research in all fields of labor economics, (ii) development of policy concepts, and (iii) dissemination of research results and concepts to the interested public.
\end{abstract}

IZA Discussion Papers often represent preliminary work and are circulated to encourage discussion. Citation of such a paper should account for its provisional character. A revised version may be available directly from the author. 


\section{ABSTRACT}

\section{Schooling, Marriage and Age of First Birth in Madagascar ${ }^{*}$}

Low female schooling attainment, early marriage and low age at first birth are major policy concerns in developing countries. This paper jointly estimated the determinants of educational attainment, marriage age and age of first birth among females 12 to 25 years of age in Madagascar, explicitly accounting for the endogeneities that arose from modeling these related outcomes simultaneously. An additional year of schooling resulted in a delay of marriage by 1.5 years. Marrying one year later delayed the age of first birth by 0.5 years. Parental education and wealth also had important effects on schooling, marriage and age at first birth: among other findings, a woman's first birth was delayed by 0.75 years for four additional years of schooling of her mother. Overall, the results provided rigorous evidence for the critical role of education - both own education and that of parents - in delaying marriage and fertility of young women.

JEL Classification: J12, J13, I20, C3

Keywords: education, marriage, fertility, joint estimation, Madagascar

Corresponding author:

David E. Sahn

Cornell University

B16 MVR Hall

Ithaca, NY 14853

USA

E-mail: David.Sahn@cornell.edu

\footnotetext{
* The work was supported by the IZA/DFID GLM | LIC Program under Grant Agreement GA-C1-RA4067. This document is an output from a project funded by the UK Department for International Development (DFID) and the Institute for the Study of Labor (IZA) for the benefit of developing countries. The views expressed are not necessarily those of DFID or IZA.
} 
Glick, Handy, and Sahn-2

\section{Introduction}

Low schooling attainment of girls, early marriage and age at first birth are major policy concerns in developing countries. Approximately one quarter of girls aged 10-14 in developing countries are not enrolled in school (Lloyd and Mensch 2008), and each year more than 14 million girls aged 15-19-most of whom are not in school — give birth (United Nations Population Fund 2005). These young women are at especially high risk for maternal mortality and morbidity; roughly one third of all deaths among females aged 15-19 in Africa are due to maternal causes (Patton et al. 2009).

Early marriage can pose significant health risks to young women and girls through multiple pathways: HIV and other sexually transmitted infection from older spouses, cervical cancer and maternal complications or mortality due to childbearing that occurs before the mother has physically matured fully (Clark et al. 2006; Nour 2006). Offspring of very young women are at an increased risk for premature birth and neonatal or infant death. Early childbearing is also associated with higher total fertility, which poses health risks through maternal morbidity and undernutrition, as well increasing mortality given per birth mortality risk. There is also considerable evidence that having a first birth at a young age reduces a woman's employment prospects (Joshi and Schultz 2007; Kim and Aassve 2006; Chun and Oh 2002).

The role of education is likely to be crucial, since staying in school is expected to delay marriage and the initiation of childbearing (Schultz 1997). Descriptive data from Madagascar are consistent with this pattern. In 2009, 68 per cent of women in Madagascar aged 20-24 with no education were married or in a stable union by age 18 , in contrast to only 28 per cent of similarly aged women with at least secondary education (INSTAT and ICF 2010). In addition to working through delays in the start of childbearing, more education can reduce total fertility by raising opportunity costs of time, since more highly educated women must give up higher earnings to stay home to raise children (Becker 1981). Further, female education is expected to lead to greater gender equality within marriage, as more educated women may have greater bargaining power within relationships (Engle 1997; Schultz 1990; Thomas and Chen 1994), including decision-making in regard to contraception (Mason 1986).

The problem of early dropout, marriage and onset of childbearing is highly relevant in Madagascar, a very poor country, which in 2005 - the time of the survey used for this studyhad a per capita GDP of \$275, and a poverty rate of 68 per cent (World Bank 2014). The primary completion rate among girls in 2005 was only around 56 per cent, slightly lower than the mean value for all of sub-Saharan Africa (SSA) (World Bank 2014). The total fertility rate in 2004 was 5.2 , which was quite high by world standards but close to the median among SSA countries. Over the period 1984-2012, total fertility fell by 1.6 births in Madagascar, slightly less than the mean decrease of 1.8 among countries in the region during this time (World Bank 2014). High fertility, in part, reflected low contraceptive use: only 29 per cent of married women in Madagascar used any type of modern contraception in 2008-09, up from 18 per cent in 2003-04 (INSTAT and ORC Macro 2005; INSTAT and ICF Macro 2010). Finally, among women aged 25-49, the median age at first marriage was 19.1 years in 2003-04 and actually decreased slightly over the next five years to 18.9 in 2008-09 (INSTAT and ORC Macro 2005; INSTAT and ICF Macro 2010). 
A great deal of evidence across many countries has documented a negative association between schooling and fertility (Ainsworth et al. 1996), although this pattern is less consistently found in SSA, where it appears to apply mostly to females with higher education levels (Gangadharan and Maitra 2001; Appleton 1996; Younger 2006; Ainsworth et al. 1996; Thomas and Maluccio 1996). ${ }^{1}$ A number of studies in Africa have also used Demographic and Health Surveys (DHS) or other cross-sectional household surveys to examine the determinants of age at marriage or age at the beginning of childbearing (Mensch et al. 2005; Mahy and Gupta 2002). However, most research on these topics in SSA has been constrained by significant methodological and data limitations. One limiting factor has been the inability to deal with the endogeneity of education to age at marriage and fertility. Endogeneity arose because, for example, young women (or their parents) with strong preferences for education and labour market success may also have had lower preferences for a large, traditional family. In other words, schooling and marriage or fertility may be jointly determined, making it improper to infer causality from the association of these outcomes. There may also be reverse causality in the relationship of education to marriage or fertility.

Among the few exceptions in the literature that accounted for schooling endogeneity for the region, Osili and Long (2008) used variation in exposure to Nigeria's universal primary enrolment policy to estimate the impact of schooling on fertility. Increasing education by one year reduced completed fertility by 0.26 births. Blunch (2007), using an instrumental variable approach, found for Ghana that higher reading test scores had a significant negative impact on the probability of a non-marital pregnancy. In non-African cases, Brien and Lillard (1994) and Angeles et al. (2005a, 2005b) estimated multiple equation models that accounted for the joint determination of education and fertility outcomes.

A second limitation of most previous work was the lack of information on family background and wealth, including parental education and income, which was likely to be important determinants of young women's schooling, age at marriage and fertility. Most crosssectional data sets, including DHS, have little or no information on these background factors, as they collect information only on the household in which a woman currently lives. Excluding such variables in modelling means that we could lack insights into these potential key determinants of the timing of marriage and childbearing; further, since they are likely correlated with included regressors such as own education, the effects of the latter may be misestimated.

In this study we attempted to better understand the impact of schooling on the timing of marriage and beginning of childbearing in Madagascar, and also investigated the role of family circumstances and background, such as household wealth, on schooling and age at marriage and first birth. We used a unique data set, the Madagascar School Progression and Academic Performance Survey (known by its French acronym, EPSPAM), to jointly model the relationships of schooling, marriage and fertility of young women. Unlike most surveys from the region, information was gathered on all children under the age of 30 of household members, whether the children lived at home or not, which was important in a context where early marriage and leaving home is common. Hence, we were able to link family (parental) background to the outcomes of interest for a representative sample of young women, overcoming the data limitation noted above. ${ }^{2}$ In addition, the household survey was complemented by richly detailed 
community and schooling surveys that provided information on local school and health infrastructure.

In our preferred, jointly estimated model of educational attainment, age at marriage and age at first birth, we found that an additional year of schooling delayed age at marriage by 1.5 years, and that marrying one year later resulted in a half-year increase in age at first birth. Family background characteristics also mattered strongly, with both parental education and assets leading to later marriage and parenthood. We also found that failure to account for the joint determination of these outcomes, and failure to include family background determinants (as most studies have done, given data limitations), both led to a substantial overestimation of the effect of education on age at marriage and at first birth.

\section{Data}

The Madagascar School Progression and Academic Performance Survey (EPSPAM), conducted jointly by the Malagasy Ministry of Education (MENRS), the Malagasy National Institute of Statistics and Cornell University in 2004-05, surveyed 2,100 households from 73 communities, including 2,336 females between 12-25 years of age at the time of the survey who had ever attended school. The survey contained detailed data on the characteristics of all household members, including education, as well as information such as household wealth and assets and demographic characteristics. See Annex A for more information on the survey.

Descriptive statistics for the variables used, reported in Table 1, indicated that 18 per cent of the 12-25-year-old, female sample were married, and 17 per cent were already parents. Childbearing before marriage was not very common, occurring for only 5 per cent of the sample. Average schooling for the sample was 5.7 years, but since just over one half of the women were still in school, mean completed years of school among this cohort were higher. Fathers and mothers had, on average, 5.5 and 4.8 years of education, respectively. The previous generation tended to marry and have children earlier: mothers of women in our sample married, on average, at age 19.8 years and had a child by age 21 .

\section{Estimation strategy}

We used an ordered probit to model completed years of schooling, and we used continuous-time hazard models to estimate age at marriage and age at first birth. We estimated these three outcomes jointly, and explicitly accounted for the endogeneities that arose from modelling these related outcomes simultaneously.

Covariates appearing in each of the three equations included year of birth and variables capturing a young woman's family background and community characteristics. Family background variables included years of education of each parent, parental mortality, an asset index formed using factor analysis (see Sahn and Stifel (2003)), and indicators of the religion and ethnicity of the head of household. Parental mortality entered as time-varying indicators in the dynamic marriage and first birth models and as a simple indicator for whether the parent died before the young woman was age 5 and age 10 in the static education model. Community 
Glick, Handy, and Sahn-5

variables included province indicators, urban residence, transportation cost to the centre of the nearest urban area, the availability of electricity and type of water sources. We also included a general measure for distance to a range of services, markets and infrastructure. This 'remoteness' index was formed by factor analysis on community distances to health services, banks, post offices, schools, taxis, courts, markets, inputs, extension services and veterinarians, as well as access to national and provincial roads, utilities, media and other markets and several measures of access to transport.

\section{Completed schooling}

For the ordered probit model of the determinants of educational attainment, we specified a latent variable, $E d u c^{*}$, with the following specification:

$$
\text { Educ }^{*}=\alpha_{0}+\alpha_{1} \text { Cohort }+\alpha_{2}^{\prime} \text { School }+\alpha_{3}^{\prime} \text { Health }+\alpha_{4}^{\prime} \text { Parents }+\alpha_{5}^{\prime} \text { Comm }+\varepsilon^{s}+\zeta^{s}
$$

For individuals who had completed their schooling, we observed that $E d u c=s$, where $s \in\{0,1, \ldots, 17\}$ was the number of completed grades. For individuals still in school, we did not know completed schooling, but we knew it would be equal to or greater than the number of completed grades at the time of the survey, that is, $E d u c \geq s$.

The vector School contained information about the primary school closest to the centre of the community, summarised in two indices and constructed using factor analysis. The "pedagogy index' is the first factor extracted from the number of blackboards per student, textbooks per student and presence or absence of a library. The 'facilities index' was the first factor, extracted from indicators of the availability at the school of electricity, medicine, toilets and gender separate toilets, recreation grounds and clean water. The School vector also included an indicator for whether the school was private, the school director's years of education and experience, the proportion of teachers with teaching degrees and the proportion of teachers with at least five years of experience.

Our information on secondary schools was limited to an indicator of whether there was a collège (junior secondary, grades 6-9) in the community and when it was opened. We created an indicator of whether there was a secondary school in the community when a girl in the survey was age 8 , to capture, in a time-varying fashion, the accessibility of secondary school. A secondary school close to home could encourage parents to enrol a child and keep her in school, given the costs (transportation or boarding, and loss of domestic labour) of enroling her at a distant secondary school. It was also possible that there was a demonstration effect of having a secondary school in the community, since parents would be better able to observe the benefits of attending secondary school. This, in turn, would encourage primary enrolment and school continuation.

The vector Health contained indicators of the presence of health and nutrition programmes, taken from community and school questionnaires. A key programme, recorded in the school survey, was Seecaline, a national government-sponsored community- and school- 
based nutrition programme. Separately, the community questionnaire collected retrospective information on the presence of any child nutrition programme in the community, including the date of inception and termination, if relevant. For each young woman, we created dummy variables, indicating whether child health and nutrition programmes were in existence at the time she was born or when she was age 10. By improving a child's health, these services potentially affected performance in school and the returns to education, and thus indirectly may have encouraged families to keep a child in school. The Seecaline programme may have had these effects as well, but also may have directly induced primary school enrolment, since the nutrition services were provided to students in schools.

A concern with these variables was that the placement and timing of a programme in a given community could not be assumed to be random. To address endogenous programme placement, we attempted to predict the presence of these health programmes using the method of Pörtner et al. (2011), who noted that the within-country ranking of community characteristics (as opposed to their levels) may have plausibly affected government programme placement decisions while having no direct effect on the outcomes we studied. However, models for programme presence, using as explanatory variables the ranks of population, remoteness and transport and shipping costs from the 2001 Madagascar commune census, did not yield any sufficiently strong predictors. Therefore, we relied on actual programme placement in our estimations. Although the lack of statistically significant programme predictors among the ranking factors just described could have indicated that programme introduction was in fact relatively orthogonal to the outcomes of interest, it would still was wise to interpret the findings for these variables with caution. We noted that for each outcome of interest, our major findings reported below — on the effects of education and family background - were robust to excluding these health programme indicators.

The vector Parents contained family background variables while Comm contained variables describing community characteristics, both discussed earlier. Finally, $\varepsilon^{s}$ was a residual term, capturing unobserved heterogeneity at the household level, which was assumed to be uncorrelated with the other explanatory variables, and $\zeta^{s}$ captured unobserved heterogeneity at the individual level. Both were assumed to be normally distributed with mean zero; the standard deviation of $\varepsilon^{S}$ was estimated, and the standard deviation of $\zeta^{s}$ was normalised to one, as is standard in probit models.

\section{Marriage}

We modelled the timing of marriage decision as a continuous-time hazard. Specifically, we estimated the following model:

$\ln h^{m}(t)=\beta_{0}+\beta_{1}$ Cohort $+\beta_{2}^{\prime}$ Age $(t)+\beta_{3}$ Educ $(t)+\beta_{4}^{\prime}$ OOS $(t)+\beta_{5}$ Health $(t)+$ $\beta_{6}^{\prime} \operatorname{Parents}(t)+\beta_{7}^{\prime} \operatorname{Comm}(t)+\beta_{8}^{\prime}$ SexRatio $+\beta_{9}^{\prime}$ MarrShare $+\varepsilon^{m}$

We assumed that a young woman became at risk for marriage beginning at age 12 . Cohort was the young woman's year of birth, and the vector $\mathrm{Age}(t)$ formed a spline that accounted for basic duration dependency. $E d u c(t)$ was years of schooling (grades completed) at 
time $t$. OOS $(t)$ formed a spline in years since stopping schooling, and thus, allowed the marriage hazard to vary in a flexible way with time out of school. The spline included nodes at three and six years after leaving school. We noted that, unlike most related studies, we had detailed grade repetition information, so that we were able to distinguish school attainment or grades completed from the actual number of years spent in school; we did not have to assume that each grade completed took one year in school. This was an important consideration in a context like Madagascar where grade repetition is common. In our sample, individuals, on average, took about three years to complete every two primary grades.

Health $(t)$ was a time-varying indicator of the presence in the community of child health and nutrition programmes at time $t$, as discussed in the previous section. In addition to the family background characteristics, also described earlier, our data provided information about the age at marriage and age at initial parenthood of each parent, which we included in the vector Parents. By doing so, we further controlled for parental characteristics and preferences that could affect marriage behaviour of their children and thus reduced the potential for unobserved heterogeneity to bias the estimates. The vector Comm contained the community characteristics detailed above.

We also included two sets of variables that described marriage market characteristics within the community. For each individual, these variables were calculated over all persons in the sample from the same cluster who fell within the range of five years younger than the individual to 20 years older. We chose these bands, because almost all women would marry within that age range; results were robust to other choices for the range). The first characteristic we used was the ratio of the number of men to women within the cohort in the cluster, which was expected to capture the relative availability of potential spouses. We allowed the impacts of this ratio to differ for rural and urban residents. Next, the vector MarrShare included the share of women in the same cluster and cohort married less than 5 years and the share of women in the same cluster and cohort married 5-10 years. These indicators were intended to capture local norms regarding age at marriage. They were calculated as of the survey date, after excluding the woman herself.

Finally, $\varepsilon^{m}$ was a residual term capturing unobserved heterogeneity. We assumed that it was normally distributed with mean zero and a standard deviation to be estimated, and that it was uncorrelated with the included explanatory variables. The results were robust to relaxing the normality assumption by using a finite mixture distribution for $\varepsilon^{m}$ (Heckman and Singer 1984).

\section{Age at first birth}

We modelled the age at initial childbearing analogously to the marriage-timing model. We estimated the following continuous-time hazard model:

$$
\begin{aligned}
& \ln h^{p}(t)=\gamma_{0}+\gamma_{1} \operatorname{Cohort}+\gamma_{2}^{\prime} A g e(t)+\gamma_{3} \operatorname{Educ}(t)+\gamma_{4}^{\prime} \operatorname{MarDur}(t)+\gamma_{5}^{\prime} H e a l t h(t)+ \\
& \gamma_{6}^{\prime} \operatorname{Parents}(t)+\gamma_{7}^{\prime} \operatorname{Comm}(t)+\varepsilon^{p}
\end{aligned}
$$

We assumed that the individual became at risk of giving birth beginning at age 12. As in the marriage model, Cohort was the young woman's year of birth, Age(t) was an age spline that 
accommodated basic duration dependence, and $E d u c(t)$ was years of schooling (grades completed) at time $t$. We also included a spline function in years of marriage, $\operatorname{MarDur}(t)$, to allow the age at first birth hazard to depend flexibly on the duration of marriage, with nodes at 3 and 6 years after marriage.

The vector Health $(t)$ included the child health and nutrition programme indicators discussed above for the marriage model, as well as indicators of the availability of birth control and the presence of family planning programmes in the community, at time $t$. We attempted to predict these potentially endogenous variables, using the approach discussed for the nutrition programme variables in the school model. Again, the results were consistent with random programme placement, in the sense that statistically significant community predictors did not emerge, though, as noted, the estimated effects were to be interpreted with caution.

Also, as in the marriage model, we included, in the vector Parents, information about the age at marriage and age at first parenthood of the mother and father, in addition to family background characteristics. Finally, $\varepsilon^{p}$ was a residual term, capturing unobserved determinants of age at first birth. As with the marriage model, this was assumed to be uncorrelated with the other explanatory variables and to have had a normal distribution with mean zero and a standard deviation to be estimated. Also as above, the results were robust to using a finite mixture distribution for $\varepsilon^{p}$.

\section{Estimation and endogeneity}

One threat to the validity of estimates of the models above was the endogeneity of key explanatory variables. In particular, marriage and first birth outcomes and a woman's education could all be determined by common, unmeasured factors, in which case the estimates would not capture a causal effect of education on the outcomes. Parents with unobserved preferences for employment success among their children could take steps to ensure both more education and later marriage for their daughters. Similarly, 'career-minded' young women could be those with strong preferences both for rewarding work and low preferences for traditional family life. This could result in a correlation between education and the disturbance in the marriage model, due to the correlation between the education and marriage disturbance terms, and which could lead to bias in the estimate of the effect of education on age at marriage. Similar concerns arose from the fact that communities differed in terms of various types of infrastructure and services that affected both education and marriage and fertility. For example, communities with high quality school facilities, leading to greater education attainment, may also have enjoyed better access to family planning and contraceptives, leading to later first birth.

With our data we could go a long way to addressing these potential sources of endogeneity. First, we were able to include a rich set of controls at both the household and community levels, using the extensive data on school facilities, teacher characteristics, community infrastructure and health services, household wealth, parents' education and other household characteristics that could serve as controls for unobserved heterogeneity. 
Second, our data set provided plausible exclusion restrictions for endogenous regressors. We used the detailed primary school data in the schooling equation, but excluded them from the marriage and age at first birth equations. We used the sex ratio and marriage share variables, described above, only in the marriage equation, and we used the birth control and family planning indicators only in the age at first birth equation. In contrast to other studies, these exclusion restrictions did not involve household-level covariates in the manner of, for example, Brien and Lillard (1994), who excluded father's occupation and income from the fertility model. Such household level variables were often not plausibly exogenous, as they were unlikely to be excludable from the model of the outcome of interest due to the presence of household preferences or other unobservables affecting both regressors and outcomes. Our exclusion restrictions, therefore, were more plausible than those in most of the existing literature, but still had potential weaknesses. For example, primary school characteristics (e.g., a progressive director or teachers) could have directly affected both education and a young a woman's attitudes toward marriage and first birth timing. Also, a young woman's prospects in the local marriage market may have influenced her choice of educational attainment.

Third, we addressed the potential correlation of regressors, such as education, with the disturbance terms in these equations by directly modelling the joint heterogeneities across these equations, following the approach of Brien and Lillard (1994). That is, we included in each model a heterogeneity term and allowed these heterogeneities to be correlated across equations. In this way, any correlation between education and the marriage disturbance that was explained by the education disturbance was accounted for, and arguably, the remaining disturbance in the marriage model was uncorrelated with education, conditional on the other regressors. We drew the heterogeneity terms at the family level, reflecting the fact that sisters were likely to have shared many unobservables. This meant that we assumed, conditional on the many covariates in our models and on family-specific heterogeneity, that outcomes of sisters were independent. Formally, letting $\sigma_{j}^{2}$ denote the variance of heterogeneity term $\varepsilon^{j}$ and $\rho_{j k}$ denote the correlation between $\varepsilon^{j}$ and $\varepsilon^{k}$, the joint distribution of the heterogeneity terms across the schooling, marriage and first birth equations was

$$
\left[\begin{array}{c}
\varepsilon^{s} \\
\varepsilon^{m} \\
\varepsilon^{p}
\end{array}\right] \sim N\left(\left[\begin{array}{l}
0 \\
0 \\
0
\end{array}\right],\left[\begin{array}{ccc}
\sigma_{s}^{2} & & \\
\rho_{s m} \sigma_{s} \sigma_{m} & \sigma_{m}^{2} & \\
\rho_{s p} \sigma_{s} \sigma_{p} & \rho_{m p} \sigma_{m} \sigma_{p} & \sigma_{p}^{2}
\end{array}\right]\right)
$$

For each of the three processes we studied, we assumed that the correlated heterogeneities were the same for all siblings in a family. Families with two or more girls in our sample provided multiple outcome observations for the same heterogeneity draw, which was necessary to identify the full variance-covariance matrix of the heterogeneity terms. Of 1,343 households in our sample, 696 had one girl in the sample, 400 had two girls, 168 had three girls, and the remaining 79 households had between four and seven girls. Again, our approach assumed that outcomes of sisters were independent, conditional on family heterogeneity and measured characteristics. We noted that we were unable to draw heterogeneity terms at the individual level, because only one education outcome was observed per woman, and very few women in our sample had multiple marriages. 
As Brien and Lillard (1994) noted, estimation of the joint model and the terms in Eq. (4) were made possible by the independence of outcome probabilities conditional on the vector of household-level heterogeneities $\left(\varepsilon^{s}, \varepsilon^{m}, \varepsilon^{p}\right)$, since this allowed the conditional outcome probabilities to be multiplied to form the joint conditional (on heterogeneities) likelihood. Integrating the joint conditional likelihood over the range of the heterogeneity components formed the joint marginal likelihood. Estimates were achieved by maximizing the joint marginal likelihood. All reported standard errors were heteroskedasticity-robust.

\section{Results}

Results of the joint estimation of the education, marriage and fertility models are presented in Table 2 .

\section{Education}

Although our main focus was the impact of education on marriage and fertility, the results for the determinants of schooling were also of interest. Using the parameter estimates in the first column of Table 2 to compute average marginal effects of key covariates on the probabilities of achieving completed primary and lower secondary (collège) school, we found that an extra year of primary school of the mother raised the probability of a girl completing secondary school by 2.3 percentage points, compared with 1.6 points for an additional year of father's education. Similarly, a one standard deviation increase in the asset index contributed to an 8.9 percentage point increase in the probability of completing primary school and an 11.2 percentage point increase in the likelihood of completing lower secondary school (Table 3).

Estimates for the characteristics of the major primary school in the community suggested that there were no statistically significant impacts on schooling attainment of the director's education level, the proportion of teachers holding a teaching degree or the proportion of teachers with more than five years of experience. A director's experience, in years, was negatively and statistically significantly associated with years of schooling. While this seemed counterintuitive, it was possible that long-standing and entrenched school directors were less creative, energetic, and motivating than their younger counterparts. Among the school pedagogy and facilities indexes, the former was positive and statistically significant.

\section{Marriage}

We next considered the marriage hazard model, estimates of which are presented in Table 2, column 2. Our main interest was in the effects of schooling. As discussed earlier, we included both the years of education (grade attainment) and the time out of school. Recall that, for a given age, these two variables were related but distinct, given repetition and different school entry age. Since years of education determined the 'zero date' for the out of school spline, there was no issue of endogeneity of years out of school conditional upon including years of education. As noted above, time out of school entered as a spline, allowing the slopes on the years out of school 
relation to be different for 0 to 3 years, 3 to 6 years, and beyond 6 years. Both spline segments for level of education and the coefficients on each of the years since leaving school were positive and statistically significant at the 1 per cent level. The positive effect of years since leaving school was expected: it suggested that, all else equal, leaving school earlier led to earlier (younger) marriage.

However, the positive effect of the level of education on marriage, conditional on time out of school, seemed counterintuitive, so warranting an explanation. In this model, education affected marriage timing in two ways. First, given that longer time out of school was associated with an increased hazard of marriage, more education mechanically delayed marriage by delaying school exit, as just noted. Second, education altered the marriage hazard after school exit, and there were two parts to this effect. First, the coefficient on years of education directly shifted the log marriage hazard. Second, education would change the age at which the out of school spline applied, and because the log hazard varied with age, the effect of time out of school on the level of the marriage hazard would vary with age. Our parameter estimates implied that, relative to a less educated woman of the same age, the marriage hazard of a more educated woman was higher upon leaving school but increased more slowly with time out of school. The net effect of these forces on marriage timing - that is to say, the net effect of education - could not be inferred directly from the parameter estimates.

To better understand the complex impacts of completed education level and the timing of leaving school, therefore, in Figure 1, we simulated the effects of one additional year of completed education on the survivor function. These simulations incorporated all of the effects described above. The baseline survivor function was the survivor function implied by estimates of our joint model. It captured the fact that the hazard of marriage was low for young women below age 16 - most women are still in school at this age - then increased rapidly so that half of the women were married by about age 21 , and about three quarters were married by age 26 . The net effect of more education was, as expected, to lower the hazard of marriage, as can be seen in the outward shift in the survivor function. The simulations indicated that an additional year of completed schooling increased the median marriage survival age - the age at which half the women would be married-by 1.5 years (Table 3 ).

As expected, the estimates in Table 2 indicated that age at marriage was also increased by more education of the mother and father. In Figure 2, we simulated the effect of a four-year increase in mother's education, taking into account both the direct effect of mother's education on the marriage hazard and the indirect effect of mother's education through its impact on the young woman's own education. An increase of four years of schooling by the mother would increase the median time to marriage by 1.6 years, an effect that is approximately double that for father's education (compare the simulated effects on median marriage age in Table 4).

Also as expected, the estimates in Table 2 implied that greater wealth reduced the marriage hazard. Table 4 shows the simulated effect of wealth on marriage timing, again taking into account the direct effect of wealth on the marriage hazard and an indirect effect operating through the young woman's educational attainment. As shown, a one standard deviation increase in the asset index delayed the median marriage age quite substantially, by 3.1 years. 
Glick, Handy, and Sahn-12

Table 2 also shows that the death of the mother also reduced the hazard of marriage. This may have occurred because of a consequent increase in the need for the daughter to remain in the household to carry out domestic work, contributing to a delay in marriage. Supporting this gender role-based interpretation was the absence of any such effect for father's death.

A final set of variables included community-level indicators designed to capture local marriage markets (availability of potential partners) and norms, as described in the previous section. The within-group ratio of unmarried men to unmarried women was not statistically significant. However, the individual hazard of marriage increased markedly with the share of women in the cluster/cohort that were married. We took this, in part, to reflect social norms and traditions regarding the appropriate age of marriage. The results could also have been capturing unobserved community characteristics, such as economic opportunities, that affected both community-level, cohort-specific marriage rates and the individual time to marriage.

\section{First birth}

We next considered the determinants of age at first childbearing (Table 2, column 3). Regarding the effect of time since marriage on the timing of first birth, we observed a positive and statistically significant effect of being married for 0-3 years, and a negative and significant estimate for being married 3-6 years. This indicates, not unexpectedly, that the hazard of having a first birth increased with time over the first three years of marriage and thereafter decreased. To help interpret these parameter estimates, in Figure 3 we simulated the effect of delaying marriage. A delay of one year was associated with an increase in the median time to age at first birth of 0.5 years, seen by reading off the horizontal distance between the baseline and simulated survival probability at the median survival time (the time at which the survivor function is 0.5 ). Thus, like Brien and Lillard (1994), our results suggested that policies (education-related or other) that led to later marriage would also have an important impact in terms of delaying the age at which women begin childbearing.

The negative and significant coefficient on the asset index indicated that greater wealth increased the time to first birth. A one standard deviation increase in assets was associated with an increase in the time to first birth of 2.4 years, somewhat less than the effect of assets on the timing of marriage (Table 5). (As with the simulations based on the marriage model, each simulation in this section captured the total effect that the explanatory variable of interest had on the first birth hazard, including any effects operating through education and marriage.) Education of the mother and father delayed first birth as well. The magnitude of the effect of father's education was again smaller than for mothers; in the case of the fathers, four additional years of schooling were associated with an increase in the age of age at first birth by 0.5 years, and in the case of mothers, by 0.75 years. The simulations also indicated that an additional year of an individual's own education delayed first birth by 0.8 years. This was a sizable effect, although the parameter on education was not statistically significant in our jointly estimated model.

Direct comparisons of our findings with previous literature were difficult, because most research focused only on the impact of own education (not that of the women's parents, as we also did) on fertility, and used as the fertility outcome the number of children born, rather than 
the age at first birth. Further, many of these studies reported simple correlations, or if they used regression frameworks, rarely dealt with the issues of education endogeneity in fertility choices. This literature for Africa (e.g., Ainsworth et al.1996), generally, showed negative correlations between women's education and fertility, though mostly for higher years of schooling, as noted earlier. Osili and Long (2008), who did control for endogeneity, found that an additional year of schooling reduced the number of children born before a woman reached age 25 by 0.26 in Nigeria. Although these results were not directly comparable with our estimation of the timing of first birth, they were consistent with our findings.

\section{Importance of our estimation strategy}

We noted the potential importance of explicitly accounting for the endogeneities that arose from modelling related outcomes simultaneously. We assessed how our findings would have differed if the modelling had not dealt with this issue.

One way to assess the importance of endogeneity due to omitted variables is to test whether the unobservable factors driving two outcomes are correlated. Table 6 presents the heterogeneity standard deviations and correlations for the joint model reported in Table 2. Each of the correlations was statistically significant, indicating that these three decisions were related by common underlying factors, and hence, that dealing with this source of endogeneity was important. As expected, the heterogeneity correlations between schooling and both marriage and age at first birth were negative: individuals who tended to attain more schooling, controlling for observables, also tended to marry later (lower marriage hazard) and have a later first birth (lower age at first birth hazard). This was consistent with an underlying preference for labour market success among such individuals. Also, as expected, the heterogeneity correlation between marriage and age at first birth was positive: individuals who tended to marry later also tended to have a later first birth, controlling for observables.

To assess the substantive consequences of ignoring this joint nature of the outcomes of interest, we compared results from our simultaneous model to those using two alternative estimation strategies. Tables 4 and 5 compare simulation results for the marriage and first birth outcomes, respectively. (Table 7 presents the key parameter estimates that were used to produce the simulation results.)

We first compared our preferred, jointly estimated model (Model 1) to a model that was the same except that we forced the heterogeneity correlations to be zero (Model 2). That is, Model 2 consisted of three separately estimated single-equation models, and the only strategy used to address the endogeneity of education in the marriage and first birth models was the inclusion of control variables. Model 2 seemed to do well at matching the effects of predetermined regressors, such as assets and parental education, to the estimates in the preferred model. However, it did not do well at replicating the effects of the key endogenous covariate, education: compared to Model 1, the effect of education on marriage in Model 2 was 60 per cent larger (Table 4), and the effect on first birth was 75 per cent larger (Table 5). This suggested that it was indeed quite important in this context to account for the fact that these outcomes were jointly determined. 
The direction of the bias in Model 2 was not surprising, given the types of concerns noted earlier. For example, parents with unobserved preferences for work success of daughters were expected to favor both more education and later marriage. In a single-equation model of marriage timing, part of the larger estimated effect of education could reflect correlation between educational attainment and preferences for later marriage. This story was consistent with the negative correlation between the heterogeneities in the education and marriage models: young women who had high education attainment tended to have a lower hazard of marriage; that is, they married later.

A second set of simulations compared our results to what was typically estimated with more restrictive data sets, in particular the Demographic and Health Surveys, which have been the primary source of data used by other researchers to examine the impact of education and other factors on fertility and marriage in African contexts. Therefore, Model 3 was limited to information that would be available in the DHS, including educational attainment, ages at marriage and first birth, birth year and age, and indicators of urban residence, province, religion and ethnicity; and it excluded the detailed community controls and information about the household in which the young woman had grown up. ${ }^{3}$

These standard data limitations imposed two major restrictions relative to our preferred joint model. First, without the detail on community covariates and family background, one was unable to make the exclusion restrictions necessary to estimate a joint model (the exclusion restrictions are especially important for distinguishing marriage and first birth outcomes). Hence, the estimation did not account for the fact that due to common unobserved variables, education was endogenous to the timing of marriage and parenthood. Second, with respect to dealing with heterogeneity of outcomes, we would not have been able to identify adequate numbers of sisters in the DHS data, because we would not have captured information on sisters not currently in the same household. This forced us to draw heterogeneities at the community level rather than at the household level. The implicit assumption-conditional independence of outcomes within communities rather than just within families - was much stronger than we made in our preferred model, especially considering the relative lack of conditioning variables in the DHS data.

We see from Tables 4 and 5 that, as with Model 2, the impact of education in the 'DHSstyle' Model 3 was substantially overestimated - even more so than in Model 2, which included the additional controls not available in the DHS. The estimated effect of one additional year of education on age at marriage was 1.5 years in our preferred model, 2.4 years in Model 2 and 4 years in Model 3. Therefore, using approaches for standard household survey data resulted in substantial upward bias in the estimated impact of education on age at marriage and first birth.

\section{Conclusions}

Our interest in the relationships of women's education, age at marriage and age at first birth was motivated by several considerations. First, early marriage and early age at initial childbearing is likely to limit opportunities for women over their life course, and early age at childbearing also imposes health risks on young women. Second, higher overall fertility (associated with early 
start to childbearing) may lead to lower investments in the health and education of each child (Quisimbuing and Maluccio 2003), contributing to the intergenerational transmission of poverty.

Another objective of this study was to understand the complex interactions of these outcomes, with a particular focus on the role played by education. Although many studies have suggested that investments in girls' schooling will contribute to delayed marriage and later initiation of childbearing, most analyses of this effect have not adequately dealt with the simultaneity of these outcomes. Our estimates, which were able to address this source of endogeneity, confirmed the importance of education in terms of delaying marriage: an additional year of education delayed marriage by approximately 1.5 years. The impact of own schooling on the timing of fertility was also found to be important, with one additional year of schooling contributing to a delay in first birth of about half a year.

We found as well that the schooling of the women's parents had an important impact on each of the outcomes studied; an additional year of maternal schooling increased a young woman's age at marriage by about a one fourth the amount of an additional year of her own schooling. Thus, it was not only the education of the woman but also of her parents that mattered, suggesting that policies that raise the education levels of girls today could have dividends as they enter the age of childbearing, and that such investments could have positive returns for future generations.

We also found important effects of family wealth on marriage and fertility behaviour. A one standard deviation increase in an index of wealth resulted in a woman marrying nearly 3 years later and having a first birth nearly 2.5 years later. These were particularly large impacts, but it would likely be far more challenging for policymakers to substantially raise wealth than to increase the education of girls, indicating again the importance of investing in female education as a way to delay marriage and the onset of childbearing.

Because causal modelling of the relationships we studied remains limited in Africa, further research on these outcomes is needed in different countries. Indeed, evidence from a range of cross-national studies have indicated that these relationships may differ dramatically from one country to the next (Ainsworth et al. 1996). This is likely due to in part to differences in social norms for women regarding schooling, marriage and childbearing; the extent of gender bias in household schooling investments; and labour market conditions and opportunities for women. For example, in countries in West Africa, unlike Madagascar, there are large gender gaps in schooling, and women have more limited access to work and employment opportunities. On the other hand, many other countries are less poor and more economically dynamic than Madagascar, providing more opportunities that may raise the opportunity cost of time for women and, potentially, the returns to investing in their education. These considerations reinforce the need for rigorous analysis in other country contexts.

Finally, on a methodological note, we found strong evidence for the influence of unmeasured heterogeneity on these decisions. We compared the results to a set of single equation models of a kind that were frequently presented in the literature, which did not account for the simultaneity of these outcomes. Relative to our preferred joint estimation strategy, the single equation method resulted in a large upward bias in the estimated impacts of education on 
marriage and age at first birth. Additionally, not including controls for family background variables and characteristics of schools and communities contributed to a further overestimate of the impact of education on these outcomes. Therefore, accounting for the joint nature of decision-making and the endogeneity of education and other key variables is critical to drawing appropriate inferences about these relationships. 
Annex A Madagascar School Progression and Academic Performance Survey (EPSPAM)

The survey, based on an earlier school-based survey of these students when they were in primary school (see Glick et al. (2005)), covered all the regions in Madagascar. Given the school-based sampling frame, our data were broadly representative, but not strictly nationally representative, of all households in Madagascar. Geographic area weights were used in the analysis to adjust for this aspect of sample design (see Glick et al. (2005)). The EPSPAM survey defined a community as the catchment area for a primary school. It collected detailed information on all schools in the community of any level, including lower secondary schools (collège) and upper secondary schools (lycée), if present. If no collège or lycée was in the community, the survey asked the distance to the nearest such school and when it had opened. Although almost all communities had a primary school, secondary schools could be very far away, especially in rural areas. The average distance to a collège was about one kilometre among urban residents, but rose to nearly eight kilometres among rural residents. Urban residents were, on average, 10 kilometres from the nearest lycée, while rural residents were, on average, over 40 kilometres away.

The community- and school-level data consisted of information on the nature and characteristics of local infrastructure. The school surveys included the experience and credentials of the school principal and management of the school, as well as the number of teachers, their qualifications and pedagogical practices, and building and classroom conditions. In total, 140 schools were included in the 73 clusters (i.e., communities) where the survey was conducted. (For communities with more than one school, we used the characteristics of the school where the largest number of cohort members attended.) In addition, from the community survey we had information about the availability of family planning services, the availability of modern contraceptives and child nutrition information. For each community, we could determine whether each service type was currently available and, if so, when it first became available. Further, we also were able to use information from a census conducted in 2001 of all of the 1395 communes in Madagascar. From this census, linked by commune identifiers to our own surveys, we obtained information on other community characteristics, such as remoteness and transportation cost to the center of the nearest urban area. (More information about the commune census is available at http://www.ilo.cornell.edu/ilo/data.html) 


\section{References}

Ahmed, Saifuddin., Qingfeng Li, Li Liu, and Amy O. Tsui. 2012. Maternal deaths averted by contraceptive use: an analysis of 172 countries, The Lancet 380(9837): 111-125.

Ainsworth, Martha, Kathleen Beegle, and Andrew Nyamete. 1996. The impact of women's schooling on fertility and contraceptive use: A study of fourteen Sub-Saharan African countries, World Bank Economic Review 10(1): 85-122.

Angeles, Gustavo, David K. Guilkey, and Thomas A. 2005a. The effects of education and family planning programs on fertility in Indonesia, Economic Development and Cultural Change 54(1): 165-201.

Angeles, Gustavo, David K. Guilkey, and Thomas A. Mroz. 2005b. The determinants of fertility in rural Peru: Program effects in the early years of the National Family Planning Program, Journal of Population Economics 18(2): 367-389.

Appleton, Simon. 1996. How does female education affect fertility? A structural model for the Côte d'Ivoire, Oxford Bulletin of Economics and Statistics 58(1): 139-166.

Becker, Gary S. 1981. A Treatise on the Family. Cambridge: Harvard University Press.

Blunch, Niels-Hugo. 2007. Skills, schooling and non-marital teenage pregnancy in Ghana. Do Adult Literacy Programs Matter? Paper presented at the 2007 Annual Meeting of the Population Association of America, 29-31 March 2007, New York, NY.

Brien, Michael J. and Lee A. Lillard. 1994. Education, marriage, and first conception in Malaysia, Journal of Human Resources, 29(4): 1167-1204.

Chun, Hyunbae and Jeungil Oh. 2002. An instrumental variable estimate of the effect of fertility on the labour force participation of married women, Applied Economics Letters 9(10): 631-634.

Clark, Shelley, Judith Bruce, and Annie Dude. 2006. Protecting young women from HIV/AIDS: The case against child and adolescent marriage, International Family Planning Perspectives 32(2): 79-88.

Engle, Patrice L. 1997. The role of men in families: achieving gender equity and supporting children, Gender and Development 5(2): 31-40.

Field, Erica and Attilla Ambrus. 2008. Early marriage, age of menarche, and female schooling attainment in Bangladesh, Journal of Political Economy 116(5): 881-930.

Gangadharan, Lata and Pushkar Maitra. 2001. Two aspects of fertility behavior in South Africa, Economic Development and Cultural Change 50(1): 183-199.

Garenne, Michel. 2004. Age at marriage and modernisation in sub-Saharan Africa, Southern African Journal of Demography 9(2): 59-79.

Glick, Peter. Harivelo Rajemison, Arsène Ravelo, Yolande Raveloarison, Mamisoa Razakamanantsoa, and David E. Sahn. 2005. The Progression through School and Academic Performance in Madagascar Study: Preliminary descriptive results. CFNPP Working Paper \#166. Ithaca, NY: Cornell Food and Nutrition Policy Program, Cornell University. 
Heckman, James and Burton Singer. 1984. A method for minimizing the impact of distributional assumptions in econometric models for duration data, Econometrica 52(2): 271-320.

Institut National de la Statisque (INSTAT) and ICF Macro. 2010. Enquête Démographique et de Santé, Madagascar 2008-2009. [Demographic Health Survey, 2008-2009.]

Antananarivo, Madagascar: INSTAT and ICF Macro. http://dhsprogram.com/pubs/pdf/FR236/FR236.pdf

Institut National de la Statisque (INSTAT) [Madagascar] and ORC Macro. 2005. Enquête Démographique et de Santé, Madagascar. Rapport de Synthèse. [Demographic Health Survey, 2003-2004. Key Findings, Madagascar.] Calverton, MD, USA: INSTAT and ORC Macro. http://dhsprogram.com/pubs/pdf/SR105/SR105MD03-04Eng.pdf

Joshi, Shareen and T. Paul Schultz. 2007. Family planning as an investment in development: Evaluation of a program's consequences in Matlab, Bangladesh. Center Discussion Paper No. 951. New Haven, CT: Economic Growth Center, Yale University.

Kim, Jungho and Arnstein Aassve. 2006. Fertility and its consequence on family labour supply, Discussion Paper No. 2162. Bonn, Germany: IZA.

Lloyd, Cynthia B. and Barbara S. Mensch. 2008. Marriage and childbirth as factors in dropping out from school: An analysis of DHS Data from sub-Saharan Africa, Population Studies 62(1): 1-13.

Mahy, Mary and Neeru Gupta. 2002. Trends and differentials in adolescent reproductive behavior in Sub-Saharan Africa. DHS Analytical Studies No. 3. Calverton, Maryland: ORC Macro.

Mason, Karen O. 1986. The status of women: Conceptual and methodological issues in demographic studies, Sociological Forum 1(2): 284-300.

Mensch, Barbara S., Susheela Singh, and John B. Casterline. 2005. Trends in the timing of first marriage among men and women in the developing world, in Cynthia B. Lloyd, Jere R. Behrman, Nelly P. Stromquist, and Barney Cohen (eds.), The Changing Transitions Adulthood in Developing Countries: Selected Studies. Washington, DC: National Academies Press, pp. 118-171.

Nour, Nawal M. 2006. Health consequences of child marriage in Africa, Emerging Infectious Diseases 12(11): 1644-1649.

Osili, Una Okonkwo and Bridget Terry Long. 2008. Does female schooling reduce fertility? Evidence from Nigeria, Journal of Development Economics 87(1): 57-75.

Patton, George C., Carolyn Coffey, Susan M. Sawyer, Russell M. Viner, Dagmar M. Haller, Krishna Bose, Theos Vox, Jane Ferguson, and Colin D. Mathers. 2009. Global patterns of mortality in young people: A systematic analysis of population health data. The Lancet 374(9693): 881-892.

Pörtner, Claus C., Kathleen Beegle, and Luc Christiaensen. 2011. Family planning and fertility: Estimating program effects using cross-sectional data. Paper presented at the 2011 Annual Meeting of the Population Association of America, 31 March-2 April, Washington, DC. 
Quisumbing, Agnes R. and John A. Maluccio. 2003. Resources at marriage and intrahousehold allocation: Evidence from Bangladesh, Ethiopia, Indonesia, and South Africa, Oxford Bulletin of Economics and Statistics 65(3): 283-327.

Sahn, David E. and David C. Stifel. 2003. Exploring alternative measures of welfare in the absence of expenditure data, Review of Income and Wealth 49(4): 463-489.

Schultz, T. Paul. 1990. Women's changing participation in the labor force: A world perspective, Economic Development and Cultural Change 38(3): 457-488.

Schultz, T. Paul. 1997. Demand for children in low income countries, in M. R. Rosenzweig and O. Stark, (eds.), Handbook of Population and Family Economics, 1A. Amsterdam: Elsevier Press, pp. 349-429.

Thomas, Duncan and Chien-Liang Chen. 1994. Income shares and shares of income: Empirical tests of models of household resource allocation. Working Paper Series 94-08. Santa Monica, CA: The Rand Corporation.

Thomas, Duncan and John Maluccio. 1996. Fertility, contraceptive choice, and public policy in Zimbabwe, World Bank Economic Review 10 (1): 189-222.

United Nations Population Fund. 2005. State of World Population 2005: The Promise of Equality: Gender Equity, Reproductive Health and the Millennium Development Goals. New York: United Nations.

World Bank. 2014. Data. Indicators. http://data.worldbank.org/indicator

Younger, Stephen D. 2006. Labor market activities and fertility. CFNPP Working Paper No. 218. Ithaca, NY: Cornell Food and Nutrition Policy Program, Cornell University. 


\section{Notes}

${ }^{1}$ One explanation for this was that average levels of schooling in Africa remain quite low, with many girls quitting school well before childbearing would begin. Hence, incremental increases in time in school may not strongly affect the timing of marriage or first birth.

${ }^{2}$ It was possible that there could be error in the reporting by parents of information about their non-resident children, but we expected this to be minor, given the significance of the outcomes they were being asked about.

${ }^{3}$ Note that an important control variable in our model was the wealth of the woman's parents, as measured by an asset index. DHS data often includes an asset index, but it applies to the woman's current household, rather than the woman's parents' household, so we excluded this variable from Model 3. 
Table 1 Descriptive statistics

\begin{tabular}{|c|c|c|}
\hline & Mean & $\begin{array}{l}\text { Standard } \\
\text { deviation }\end{array}$ \\
\hline \multicolumn{3}{|l|}{ Personal characteristics } \\
\hline Birth year (cohort) & 1986 & 3.70 \\
\hline Age at survey & 17.30 & 3.73 \\
\hline In school at survey & 0.56 & 0.50 \\
\hline Years of education at survey & 5.71 & 2.62 \\
\hline Married at survey & 0.18 & 0.38 \\
\hline Parent at survey & 0.17 & 0.38 \\
\hline \multicolumn{3}{|l|}{ School characteristics } \\
\hline Private & 0.30 & 0.46 \\
\hline Seecaline & 0.45 & 0.50 \\
\hline Director years of education & 11.09 & 2.09 \\
\hline Director experience & 10.03 & 8.70 \\
\hline Proportion of teachers with teaching degree & 0.52 & 0.32 \\
\hline Proportion of teachers more than 5 years experience & 0.70 & 0.28 \\
\hline Pedagogy index & -0.03 & 0.46 \\
\hline Facilities index & -0.01 & 0.77 \\
\hline Secondary school in community at age 8 & 0.85 & 0.36 \\
\hline Secondary school in community at age 14 & 0.88 & 0.32 \\
\hline \multicolumn{3}{|l|}{ Health programme exposure } \\
\hline Birth control in community at age 0 & 0.05 & 0.21 \\
\hline Birth control in community at age 10 & 0.16 & 0.37 \\
\hline Birth control in community at survey & 0.37 & 0.48 \\
\hline Family planning info in community at age 0 & 0.06 & 0.24 \\
\hline Family planning info in community at age 10 & 0.28 & 0.45 \\
\hline Family planning info in community at survey & 0.65 & 0.48 \\
\hline Child nutrition info in community at age 0 & 0.03 & 0.16 \\
\hline Child nutrition info in community at age 10 & 0.14 & 0.35 \\
\hline Child nutrition info in community at survey & 0.65 & 0.48 \\
\hline \multicolumn{3}{|l|}{ Parent characteristics } \\
\hline Asset index & 0.10 & 0.97 \\
\hline Father's years of education & 5.52 & 3.72 \\
\hline Missing & 0.06 & 0.24 \\
\hline Father died before girl age 5 & 0.01 & 0.12 \\
\hline Father died before girl age 10 & 0.04 & 0.19 \\
\hline Father died before survey & 0.08 & 0.27 \\
\hline Father age at marriage & 25.43 & 5.25 \\
\hline Missing & 0.40 & 0.49 \\
\hline Father never married & 0.02 & 0.15 \\
\hline Father age at first birth & 26.10 & 5.68 \\
\hline Missing & 0.29 & 0.46 \\
\hline Mother's years of education & 4.81 & 3.35 \\
\hline Missing & 0.04 & 0.20 \\
\hline Mother died before girl age 5 & 0.01 & 0.07 \\
\hline Mother died before girl age 10 & 0.01 & 0.12 \\
\hline Mother died before survey & 0.03 & 0.18 \\
\hline Mother age at marriage & 19.81 & 3.93 \\
\hline Missing & 0.28 & 0.45 \\
\hline Mother never married & 0.04 & 0.20 \\
\hline
\end{tabular}


Glick, Handy, and Sahn-' 3

\begin{tabular}{|c|c|c|}
\hline Mother age at first birth & 20.93 & 5.15 \\
\hline Missing & 0.17 & 0.38 \\
\hline \multicolumn{3}{|l|}{ Religion } \\
\hline Traditional & 0.10 & 0.30 \\
\hline Catholic & 0.38 & 0.49 \\
\hline Protestant & 0.41 & 0.49 \\
\hline Other & 0.11 & 0.31 \\
\hline \multicolumn{3}{|l|}{ Ethnicity } \\
\hline Antandroy & 0.07 & 0.25 \\
\hline Betsileo & 0.18 & 0.39 \\
\hline Betsimisaraka & 0.11 & 0.31 \\
\hline Merina & 0.25 & 0.43 \\
\hline Tsimihety & 0.07 & 0.25 \\
\hline Other & 0.32 & 0.47 \\
\hline \multicolumn{3}{|l|}{ Community characteristics } \\
\hline Urban & 0.29 & 0.46 \\
\hline \multicolumn{3}{|l|}{ Province } \\
\hline Antananarivo & 0.21 & 0.41 \\
\hline Fianarantsoa & 0.25 & 0.43 \\
\hline Toamasina & 0.18 & 0.39 \\
\hline Mahajanga & 0.13 & 0.33 \\
\hline Toliara & 0.13 & 0.34 \\
\hline Antsiranana & 0.10 & 0.30 \\
\hline Electricity in community at age 0 & 0.25 & 0.43 \\
\hline Electricity in community at age 10 & 0.32 & 0.47 \\
\hline Electricity in community at survey & 0.37 & 0.48 \\
\hline Public water faucet & 0.49 & 0.50 \\
\hline Private water faucet & 0.25 & 0.43 \\
\hline Well water & 0.58 & 0.49 \\
\hline Surface water & 0.73 & 0.45 \\
\hline Remoteness index $(1=$ least remote $; 5=$ most remote $)$ & 2.38 & 1.29 \\
\hline Transportation cost $(10,000 \mathrm{FMG})$ & 5.31 & 6.18 \\
\hline \multicolumn{3}{|l|}{ Marriage market (within cohort) } \\
\hline Rural sex ratio within cohort & 1.11 & 0.24 \\
\hline Urban sex ratio within cohort & 0.99 & 0.12 \\
\hline Share of women in cohort married less than 5 years & 0.11 & 0.05 \\
\hline Share of women in cohort married 5 to 10 years & 0.09 & 0.04 \\
\hline Observations & \multicolumn{2}{|c|}{2,336} \\
\hline
\end{tabular}

Note: For marriage market variables, cohort was defined as individuals within the woman's community who were between five years younger than the woman and twenty years older than the woman, as women were almost certain to marry men within this age range. 
Table 2 Estimated joint model of schooling, marriage and first birth

\begin{tabular}{|c|c|c|c|}
\hline & $\begin{array}{c}\text { Schooling } \\
\text { (ordered probit) }\end{array}$ & $\begin{array}{l}\text { Marriage } \\
\text { (hazard) }\end{array}$ & $\begin{array}{l}\text { Age at first birth } \\
\text { (hazard) }\end{array}$ \\
\hline \multicolumn{4}{|l|}{ Personal characteristics } \\
\hline Constant & $\begin{array}{l}-247.44 * * * \\
(38.91)\end{array}$ & & \\
\hline Birth year (cohort) & $\begin{array}{l}0.13 * * * \\
(0.02)\end{array}$ & $\begin{array}{l}0.11 * * * \\
(0.04)\end{array}$ & $\begin{array}{l}-0.07 \\
(0.06)\end{array}$ \\
\hline \multicolumn{4}{|l|}{ Age spline } \\
\hline Age 12 intercept & & $\begin{array}{l}-231.88 * * * \\
(84.75)\end{array}$ & $\begin{array}{r}128.12 \\
(111.15)\end{array}$ \\
\hline Age $12-14.8$ slope & & $\begin{array}{l}1.00 * * * \\
(0.35)\end{array}$ & $\begin{array}{l}1.35 * * * \\
(0.46)\end{array}$ \\
\hline Age $14.8-17.6$ slope & & $\begin{array}{l}-0.50 * * * \\
(0.12)\end{array}$ & $\begin{array}{l}1.16 * * * \\
(0.19)\end{array}$ \\
\hline Age 17.6-20.4 slope & & $\begin{array}{l}-0.19 * \\
(0.11)\end{array}$ & $\begin{array}{l}0.23 * \\
(0.13)\end{array}$ \\
\hline Age 20.4-23.2 slope & & $\begin{array}{l}-0.35 * * \\
(0.15)\end{array}$ & $\begin{array}{l}0.29 * \\
(0.15)\end{array}$ \\
\hline Age $23.2-26$ slope & & $\begin{array}{l}-0.33 \\
(0.36)\end{array}$ & $\begin{array}{l}-0.40 \\
(0.54)\end{array}$ \\
\hline \multicolumn{4}{|l|}{ Endogenous outcomes } \\
\hline Years of education & & $\begin{array}{l}0.46 * * * \\
(0.09)\end{array}$ & $\begin{array}{r}0.01 \\
(0.09)\end{array}$ \\
\hline \multicolumn{4}{|l|}{ Out of school spline } \\
\hline $0-3$ years & & $\begin{array}{l}0.82 * * * \\
(0.13)\end{array}$ & \\
\hline $3-6$ years & & $\begin{array}{l}0.33 * * * \\
(0.10)\end{array}$ & \\
\hline $6+$ years & & $\begin{array}{l}0.40^{* * *} \\
(0.10)\end{array}$ & \\
\hline \multicolumn{4}{|l|}{ Marriage duration spline } \\
\hline $0-3$ years & & & $\begin{array}{l}2.03 * * * \\
(0.32)\end{array}$ \\
\hline $3-6$ years & & & $\begin{array}{l}-1.94 * * * \\
(0.57)\end{array}$ \\
\hline $6+$ years & & & $\begin{array}{l}1.53 * * \\
(0.71)\end{array}$ \\
\hline \multicolumn{4}{|l|}{ School characteristics } \\
\hline Private & $\begin{array}{l}0.57^{* *} \\
(0.35)\end{array}$ & & \\
\hline Seecaline & $\begin{array}{l}1.19^{* * *} \\
(0.16)\end{array}$ & & \\
\hline Director years of education & $\begin{array}{r}0.02 \\
(0.05)\end{array}$ & & \\
\hline Director experience & $\begin{array}{l}-0.02 * \\
(0.01)\end{array}$ & & \\
\hline Proportion of teachers with teaching degree & $\begin{array}{r}0.59 \\
(0.44)\end{array}$ & & \\
\hline $\begin{array}{l}\text { Proportion of teachers more than } 5 \text { years } \\
\text { experience }\end{array}$ & $\begin{array}{r}0.37 \\
(0.39)\end{array}$ & & \\
\hline
\end{tabular}




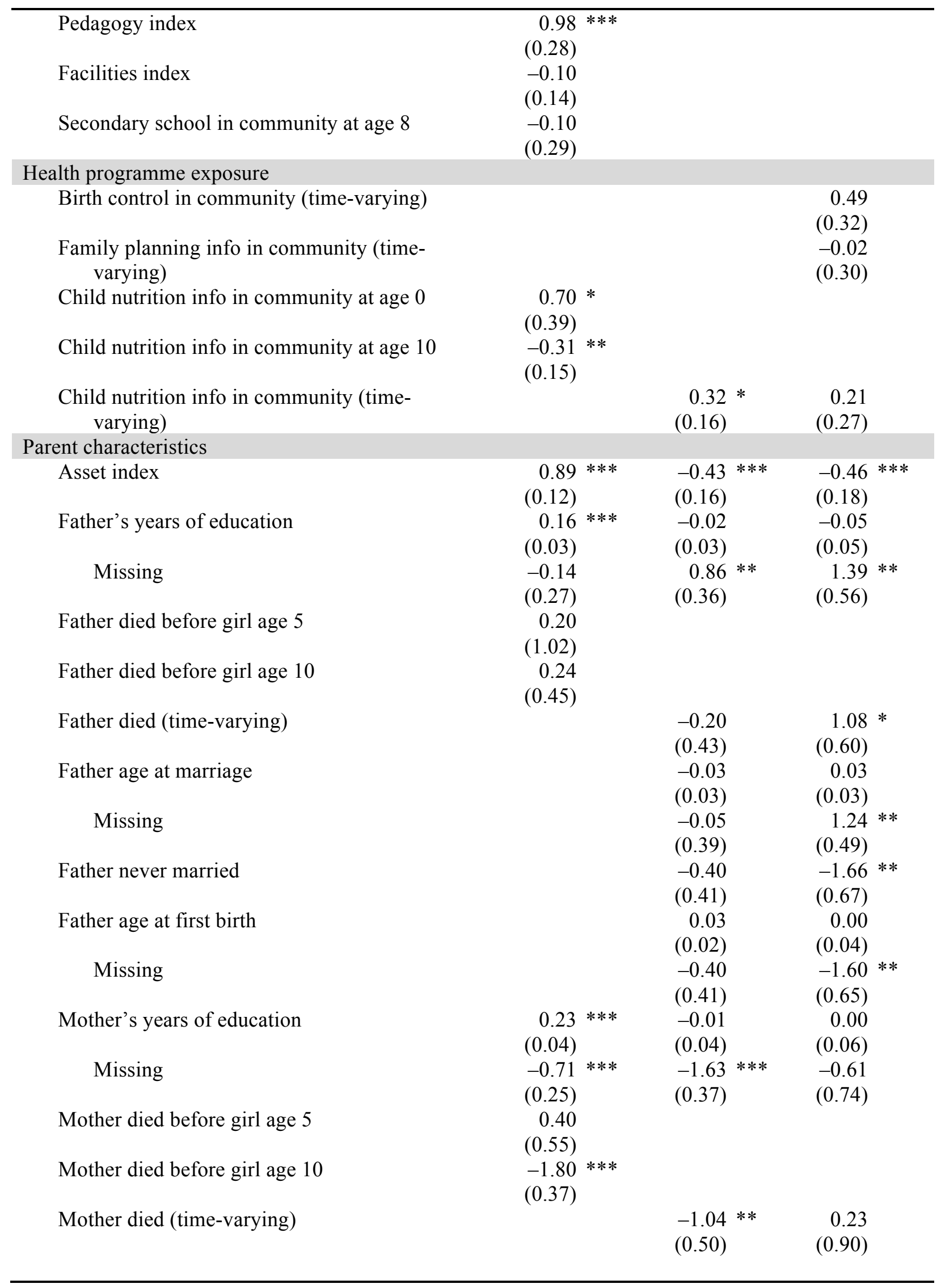




\begin{tabular}{|c|c|c|c|}
\hline Mother age at marriage & & $\begin{array}{r}0.00 \\
(0.04)\end{array}$ & $\begin{array}{r}0.02 \\
(0.09)\end{array}$ \\
\hline Missing & & $\begin{array}{r}0.18 \\
(0.39)\end{array}$ & $\begin{array}{l}-1.18 * * \\
(0.57)\end{array}$ \\
\hline Mother never married & & $\begin{array}{l}-0.53 \\
(0.46)\end{array}$ & $\begin{array}{r}0.12 \\
(0.81)\end{array}$ \\
\hline Mother age at first birth & & $\begin{array}{l}-0.01 \\
(0.02)\end{array}$ & $\begin{array}{l}-0.01 \\
(0.03)\end{array}$ \\
\hline Missing & & $\begin{array}{l}1.75 * * * \\
(0.46)\end{array}$ & $\begin{array}{l}2.36 * * \\
(0.99)\end{array}$ \\
\hline \multicolumn{4}{|l|}{ Religion } \\
\hline Traditional & $\begin{array}{l}-0.69 * \\
(0.36)\end{array}$ & $\begin{array}{r}0.41 \\
(0.31)\end{array}$ & $\begin{array}{r}0.26 \\
(0.52)\end{array}$ \\
\hline Catholic & $\begin{array}{r}0.12 \\
(0.19)\end{array}$ & $\begin{array}{l}-0.01 \\
(0.16)\end{array}$ & $\begin{array}{r}0.29 \\
(0.22)\end{array}$ \\
\hline Other & $\begin{array}{l}-0.20 \\
(0.27)\end{array}$ & $\begin{array}{r}0.05 \\
(0.33)\end{array}$ & $\begin{array}{r}0.29 \\
(0.35)\end{array}$ \\
\hline \multicolumn{4}{|l|}{ Ethnicity } \\
\hline Antandroy & $\begin{array}{l}-1.26 * * * \\
(0.29)\end{array}$ & $\begin{array}{r}0.21 \\
(0.45)\end{array}$ & $\begin{array}{l}-0.12 \\
(0.88)\end{array}$ \\
\hline Betsileo & $\begin{array}{r}0.56 \\
(0.53)\end{array}$ & $\begin{array}{r}0.15 \\
(0.30)\end{array}$ & $\begin{array}{r}0.07 \\
(0.54)\end{array}$ \\
\hline Betsimisaraka & $\begin{array}{l}-0.84 * * * \\
(0.28)\end{array}$ & $\begin{array}{r}0.46 \\
(0.37)\end{array}$ & $\begin{array}{r}0.46 \\
(0.46)\end{array}$ \\
\hline Merina & $\begin{array}{l}-0.31 \\
(0.25)\end{array}$ & $\begin{array}{l}0.87 \text { *** } \\
(0.27)\end{array}$ & $\begin{array}{c}0.82 \\
(0.44)\end{array}$ \\
\hline Tsimihety & $\begin{array}{l}-0.02 \\
(0.22)\end{array}$ & $\begin{array}{r}0.22 \\
(0.33)\end{array}$ & $\begin{array}{l}-0.40 \\
(0.42)\end{array}$ \\
\hline \multicolumn{4}{|l|}{ Community characteristics } \\
\hline Urban & $\begin{array}{l}-0.07 \\
(0.32)\end{array}$ & $\begin{array}{r}0.18 \\
(0.29)\end{array}$ & $\begin{array}{r}0.36 \\
(0.28)\end{array}$ \\
\hline \multicolumn{4}{|l|}{ Province } \\
\hline Fianarantsoa & $\begin{array}{l}-0.28 \\
(0.35)\end{array}$ & $\begin{array}{r}0.31 \\
(0.37)\end{array}$ & $\begin{array}{r}0.66 \\
(0.55)\end{array}$ \\
\hline Toamasina & $\begin{array}{l}-0.02 \\
(0.36)\end{array}$ & $\begin{array}{r}0.21 \\
(0.36)\end{array}$ & $\begin{array}{r}0.35 \\
(0.56)\end{array}$ \\
\hline Mahajanga & $\begin{array}{l}-0.97 \\
(0.66)\end{array}$ & $\begin{array}{l}0.77 \text { ** } \\
(0.38)\end{array}$ & $\begin{array}{r}0.50 \\
(0.62)\end{array}$ \\
\hline Toliara & $\begin{array}{l}-0.08 \\
(0.38)\end{array}$ & $\begin{array}{r}0.67 \\
(0.48)\end{array}$ & $\begin{array}{r}1.60 \\
(1.08)\end{array}$ \\
\hline Antsiranana & $\begin{array}{r}0.25 \\
(0.45)\end{array}$ & $\begin{array}{r}0.89 \\
(0.55)\end{array}$ & $\begin{array}{l}2.48 \text { *** } \\
(0.72)\end{array}$ \\
\hline Electricity in community at age 0 & $\begin{array}{l}-0.18 \\
(0.38)\end{array}$ & & \\
\hline Electricity in community at age 10 & $\begin{array}{r}0.47 \\
(0.48)\end{array}$ & & \\
\hline Electricity in community (time-varying) & & $\begin{array}{l}-0.07 \\
(0.22)\end{array}$ & $\begin{array}{l}-0.04 \\
(0.61)\end{array}$ \\
\hline Public water faucet & $\begin{array}{l}-0.24 \\
(0.22)\end{array}$ & $\begin{array}{l}-0.07 \\
(0.19)\end{array}$ & $\begin{array}{l}-0.09 \\
(0.48)\end{array}$ \\
\hline Private water faucet & $-0.96 * *$ & 0.15 & 0.33 \\
\hline
\end{tabular}




\begin{tabular}{|c|c|c|c|}
\hline & $(0.46)$ & $(0.35)$ & $(0.36)$ \\
\hline Well water & $0.80 * * *$ & $\begin{array}{l}-0.05 \\
(029)\end{array}$ & $\begin{array}{r}0.12 \\
(0.34)\end{array}$ \\
\hline Surface water & -0.35 & -0.06 & -0.50 \\
\hline $\begin{array}{l}\text { Remoteness index ( } 1=\text { least remote; } 5=\text { most } \\
\text { remote })\end{array}$ & $\begin{array}{l}-0.21 * * \\
(0.09)\end{array}$ & $0.21 * *$ & $\begin{array}{r}0.24 \\
(0.16)\end{array}$ \\
\hline Transportation cost (10,000 FMG) & $\begin{array}{r}0.03 \\
(0.02)\end{array}$ & $\begin{array}{l}-0.01 \\
(0.02)\end{array}$ & $\begin{array}{l}-0.01 \\
(0.03)\end{array}$ \\
\hline \multicolumn{4}{|l|}{ Marriage market } \\
\hline Rural sex ratio within cohort & & $\begin{array}{l}-0.15 \\
(0.33)\end{array}$ & \\
\hline Urban sex ratio within cohort & & $\begin{array}{r}0.62 \\
(0.63)\end{array}$ & \\
\hline $\begin{array}{l}\text { Share of women in cohort married less than } 5 \\
\text { years }\end{array}$ & & $\begin{array}{r}2.75 \\
(2.17)\end{array}$ & \\
\hline Share of women in cohort married 5 to 10 years & & $\begin{array}{l}5.83 * * * \\
(2.17)\end{array}$ & \\
\hline Observations & 2,336 & 2,336 & 2,336 \\
\hline
\end{tabular}

Notes: Heteroskedasticity-robust standard errors in parentheses. For marriage market variables, cohort was defined as individuals within the woman's community who were between five years younger than the woman and twenty years older than the woman, as women were almost certain to marry men within this age range.

* Significant at the $10 \%$ level.

** Significant at the $5 \%$ level.

*** Significant at the $1 \%$ level. 
Table 3 Schooling model average marginal effects

\begin{tabular}{lcc}
\hline & \multicolumn{2}{c}{ Change in probability of finishing... } \\
Variable & Primary (grade 5) & Collège (grade 9) \\
\hline $\begin{array}{l}\text { Additional year of } \\
\text { father's education }\end{array}$ & 0.016 & 0.020 \\
$\begin{array}{l}\text { Additional year of } \\
\text { mother's education }\end{array}$ & 0.023 & 0.029 \\
$\begin{array}{l}1 \text { standard deviation } \\
\text { increase in asset index }\end{array}$ & 0.089 & 0.112 \\
$\begin{array}{l}\text { Seecaline } \\
\begin{array}{l}\text { Mother's death before } \\
\text { child age 10 }\end{array}\end{array}$ & 0.119 & 0.149 \\
\hline
\end{tabular}

Note: Figures are average marginal effects based on the joint estimation results presented in Table 2. 
Table 4 Simulated effects of selected variables on median marriage survivor age

\begin{tabular}{|c|c|c|c|}
\hline & $\begin{array}{l}\text { Joint model with } \\
\text { correlated } \\
\text { heterogeneities } \\
\text { (Model 1) }\end{array}$ & $\begin{array}{l}\text { Single equations, } \\
\text { with endogenous } \\
\text { regressors } \\
\text { (Model 2) }\end{array}$ & $\begin{array}{c}\text { Single equations, } \\
\text { DHS variables } \\
\text { (Model 3) }\end{array}$ \\
\hline Baseline & 21.7 & 21.4 & 21.9 \\
\hline Effect of one additional year of education & 1.5 & 2.4 & 4.0 \\
\hline Effect of one std. dev. increase in assets & 3.1 & 3.0 & \\
\hline $\begin{array}{l}\text { Effect of four more years of mother's } \\
\text { education }\end{array}$ & 1.6 & 1.9 & \\
\hline $\begin{array}{l}\text { Effect of four more years of father's } \\
\text { education }\end{array}$ & 0.7 & 0.8 & \\
\hline Effect of Seecaline nutrition programme & 1.8 & 3.0 & \\
\hline
\end{tabular}

Note: The median survivor age is the age at which the estimated survivor function is 0.5 . 
Table 5 Simulated effects of selected variables on median first birth survivor age

\begin{tabular}{lccc}
\hline & $\begin{array}{c}\text { Joint model with } \\
\text { correlated } \\
\text { heterogeneities } \\
\text { (Model 1) }\end{array}$ & $\begin{array}{c}\text { Single equations, } \\
\text { with endogenous } \\
\text { regressors } \\
\text { (Model 2) }\end{array}$ & $\begin{array}{c}\text { Single equations, } \\
\text { DHS variables } \\
\text { (Model 3) }\end{array}$ \\
\hline Baseline & 21.6 & 21.6 & 21.3 \\
Effect of one additional year of education & 0.8 & 1.4 & 1.7 \\
$\begin{array}{l}\text { Effect of one std. dev. increase in assets } \\
\text { Effect of four more years of mother's } \\
\text { education } \\
\begin{array}{l}\text { Effect of four more years of father's } \\
\text { education }\end{array}\end{array}$ & 2.4 & 2.2 & \\
$\begin{array}{l}\text { Effect of Seecaline nutrition programme } \\
\text { Effect of delaying marriage one year }\end{array}$ & 0.8 & 0.6 & \\
\hline
\end{tabular}

Note: The median survivor age is the age at which the estimated survivor function is 0.5 . 
Table 6 Heterogeneity standard deviations and correlations from joint estimation

\begin{tabular}{lccc}
\hline & Schooling $\left(\varepsilon^{s}\right)$ & Marriage $\left(\varepsilon^{m}\right)$ & First birth $\left(\varepsilon^{p}\right)$ \\
\hline Schooling $\left(\varepsilon^{s}\right)$ & $1.93 * * *$ & & \\
& $(0.08)$ & & \\
Marriage $\left(\varepsilon^{m}\right)$ & $-0.38^{*} *$ & $(0.28)$ & \\
& $(0.21)$ & $0.65 * * *$ & $2.18^{* * *}$ \\
First birth $\left(\varepsilon^{p}\right)$ & $-0.18^{*}$ & $(0.08)$ & $(0.52)$ \\
\hline
\end{tabular}

Note: Diagonal elements are standard deviations; off-diagonal elements are correlations.

Heteroskedasticity-robust standard errors in parentheses.

* Significant at the $10 \%$ level.

** Significant at the 5\% level.

*** Significant at the $1 \%$ level. 
Table 7 Comparison of parameter estimates across models

\begin{tabular}{lcc}
\hline & $\begin{array}{c}\text { Joint model } \\
\text { with correlated } \\
\text { heterogeneities } \\
\text { (Model 1) }\end{array}$ & $\begin{array}{c}\text { Single } \\
\text { equations, with } \\
\text { endogenous } \\
\text { regressors } \\
\text { (Model 2) }\end{array}$ \\
\hline Schooling model & & \\
Asset index & $0.89^{* * *}$ & $0.73 * * *$ \\
Father's years of education & $(0.12)$ & $(0.12)$ \\
Mother's years of education & $0.16^{* * *}$ & $0.15^{* * *}$ \\
Seecaline & $(0.03)$ & $(0.03)$ \\
& $0.23 * * *$ & $0.25 * * *$ \\
$(0.04)$ & $(0.03)$ \\
$1.19 * * *$ & $1.24 * * *$
\end{tabular}

Marriage model

Years of education

$\begin{array}{ccc}0.46^{* * *} & 0.39^{* * *} & 0.29 * * * \\ (0.09) & (0.08) & (0.06)\end{array}$

Out of school spline

$$
\begin{aligned}
& \text { 0-3 years } \\
& \text { 3-6 years } \\
& 6+\text { years }
\end{aligned}
$$$$
0.82 * * *
$$$$
(0.13)
$$$$
0.33 * * *
$$$$
(0.10)
$$$$
0.40 * * *
$$$$
(0.10)
$$$$
-0.43 * * *
$$

Asset index

$$
\begin{aligned}
& 0.93 * * * \\
& (0.11)
\end{aligned}
$$$$
0.90 * * *
$$$$
0.33 * * *
$$$$
(0.10)
$$$$
(0.09)
$$$$
0.26 * * *
$$$$
0.43 * * *
$$$$
(0.08)
$$$$
(0.09)
$$$$
0.34 * * *
$$$$
-0.29 * * *
$$$$
-0.02
$$

Father's years of education

Mother's years of education

(0.04)

0.01

(0.03)

First birth model

Years of education

Asset index

Father's years of education

Mother's years of education

$\begin{array}{rrr}0.01 & -0.10 & -0.05 * \\ (0.09) & (0.06) & (0.03) \\ -0.46 * * & -0.31 & \\ (0.18) & (0.20) & \\ -0.05 & -0.03 & \\ (0.05) & (0.04) & \\ 0.00 & 0.03 & \\ (0.06) & (0.05) & \end{array}$


Glick, Handy, and Sahn-, 3

Marriage duration spline

\begin{tabular}{lccc}
$0-3$ years & $2.03 * * *$ & $2.46 * * *$ & $1.37 * * *$ \\
& $(0.32)$ & $(0.31)$ & $(0.12)$ \\
3-6 years & $-1.94 * * *$ & $-2.00 * * *$ & $-2.06 * * *$ \\
& $(0.57)$ & $(0.58)$ & $(0.48)$ \\
6+ years & $1.53 * *$ & $1.60 * *$ & \\
& $(0.71)$ & $(0.78)$ & \\
\hline
\end{tabular}

Note: Heteroskedasticity-robust standard errors in parentheses.

* Significant at the $10 \%$ level.

** Significant at the 5\% level.

*** Significant at the $1 \%$ level. 
Glick, Handy, and Sahn-34

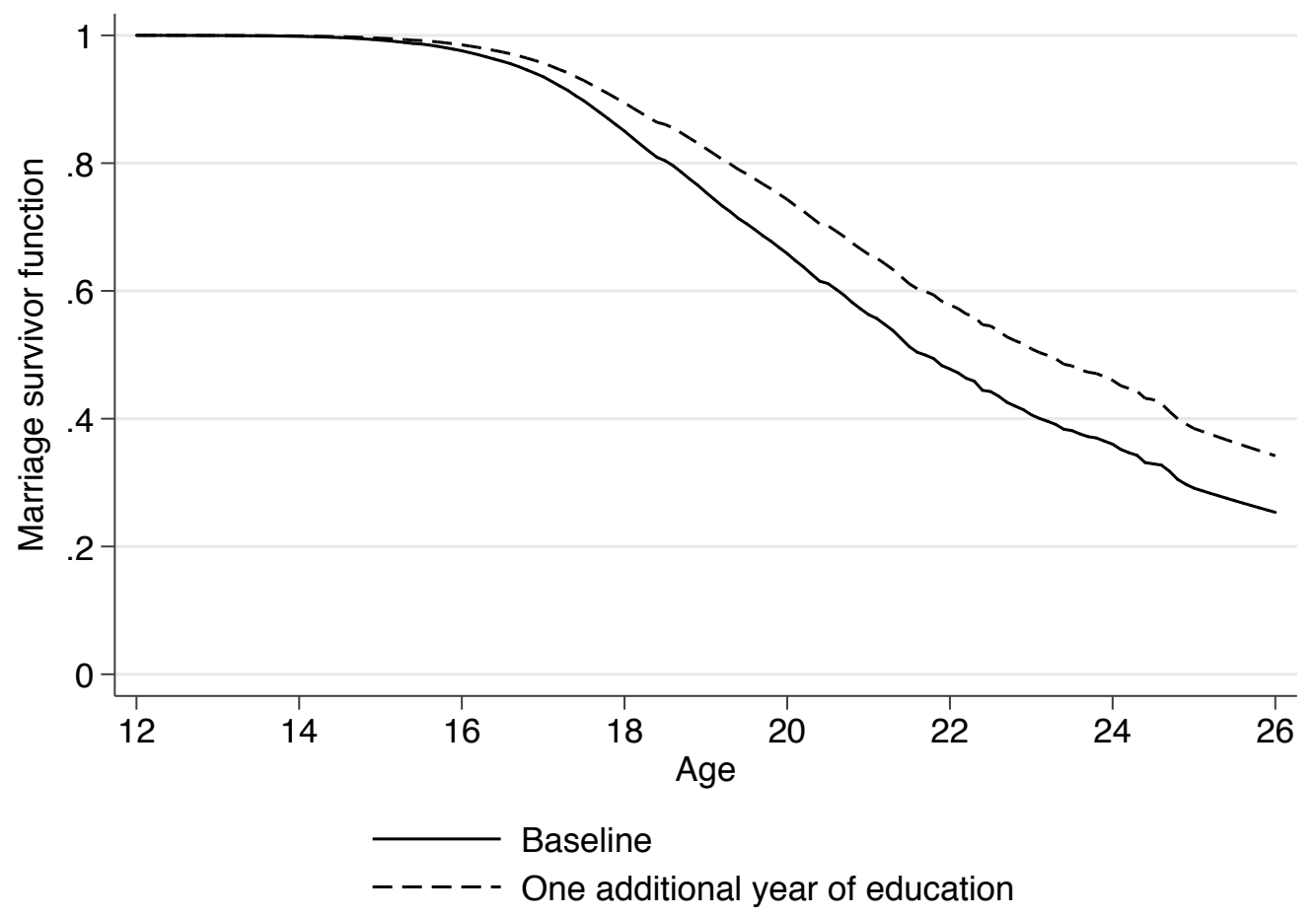

Figure 1 Simulated effect of education on marriage survivor function 
Glick, Handy, and Sahn-35

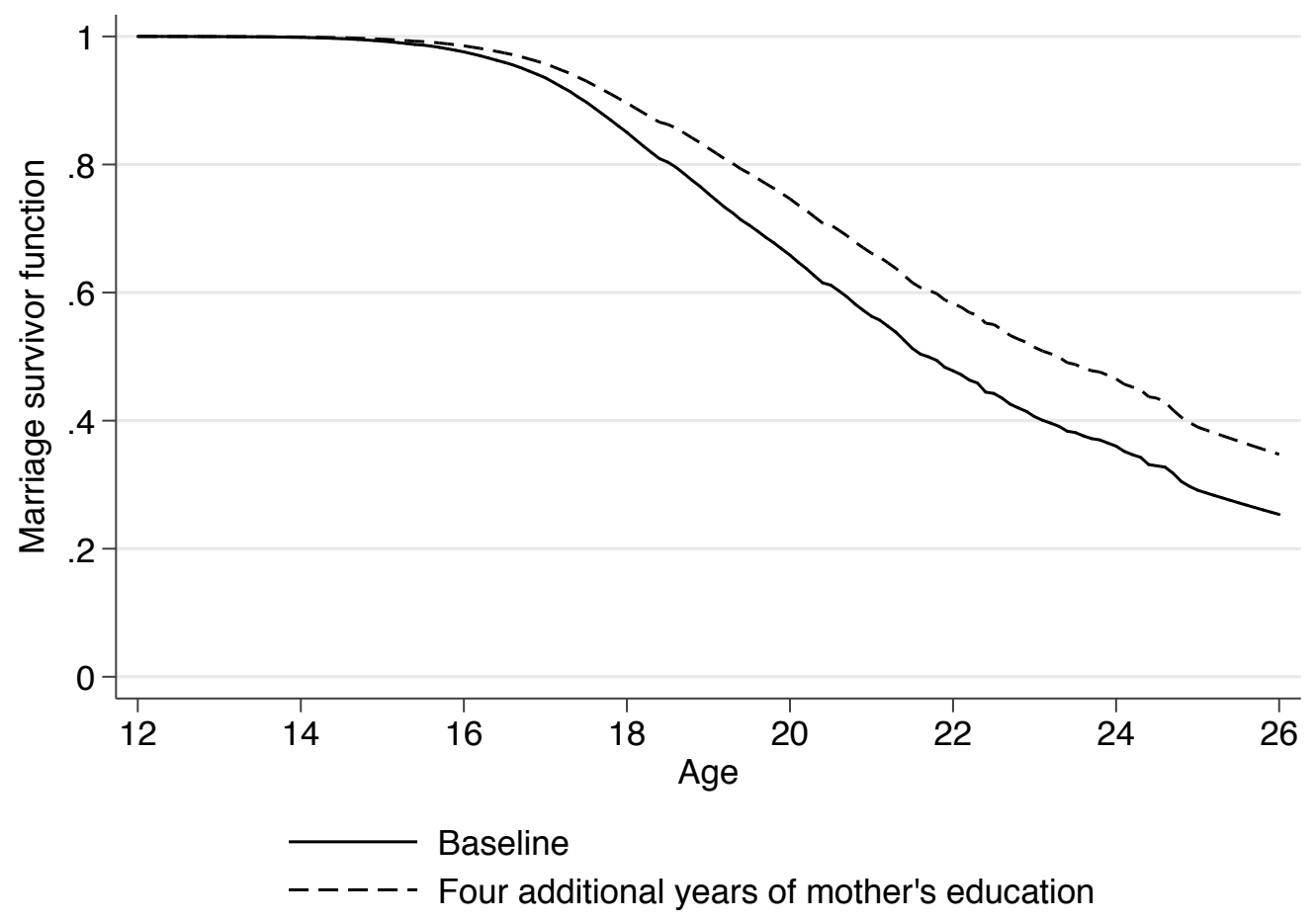

Figure 2 Simulated effect of mother's education on marriage survivor function 
Glick, Handy, and Sahn-36

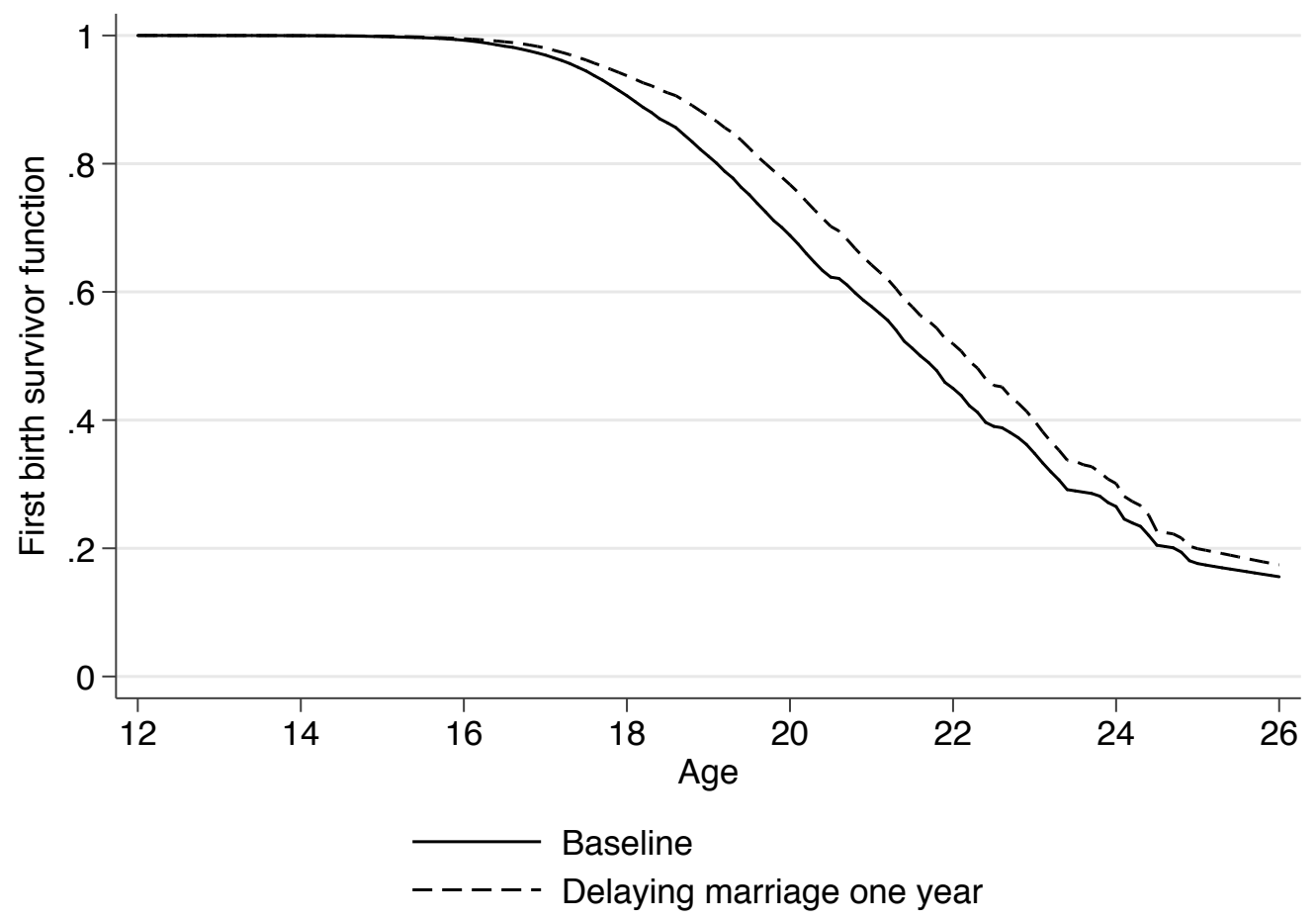

Figure 3 Simulated effect of age at marriage on first birth survivor function 